\title{
Pengaruh Kualitas Pelayanan Terhadap Kepuasan Pelanggan Jasa Service Pada PT. Astra International Tbk. - Daihatsu Malalayang
}

\author{
Gisyel Angely \\ Johny Revo Elia Tampi \\ Danny David Samuel Mukuan \\ Jurusan Ilmu Administrasi, Program studi Administrasi Bisnis \\ Fakultas Ilmu Sosial dan Politik, Universitas Sam Ratulangi \\ angelygisyel@gmail.com
}

\begin{abstract}
The purpose of this study was to study the effect of service quality consisting of tangible, reliability, responsiveness, assurance, and empathy strengthening towards customer satisfaction. Regarding the problem in this study, whether the service quality offered to customer satisfaction services at PT. Astra International Tbk. - Daihatsu Malalayang. This type of research is quantitative research with descriptive research. The populations in this study were all service customers at PT. Astra International Tbk. - Daihatsu Malalayang, with a sample of 99 respondents. Technique analysis data uses multiple linear regression, $t$ test, $f$ test, and test coefficient of determination $\left(R^{2}\right)$. Based on the results of multiple linear regression analysis that includes simultaneous tangible, reliability, responsiveness, assurance, and empathy strengthen the service satisfaction of customers at PT. Astra International Tbk. - Daihatsu Malalayang by 54.0\%. While the variables of reliability, responsiveness, and assurance are not partial to customer service satisfaction at PT. Astra International Tbk. - Daihatsu Malalayang. And the most dominant service quality variable is empathy.
\end{abstract}

Keywords: Service quality, Customer Satisfaction.

\section{Pendahuluan}

Perkembangan dan kemajuan perekonomian Indonesia yang pesat saat ini tidak hanya di dominasi dengan industri manufaktur, tetapi diikuti juga dengan industri otomotif. Perkembangan industri otomotif saat ini tumbuh cepat, sehingga menimbulkan persaingan yang sangat ketat di antara industri otomotif. Hal ini menyebabkan sektor jasa yang bergerak dibidang perawatan kendaraan berlomba-lomba melakukan inovasi, meningkatkan produksi dan membangun hubungan yang baik dengan pelanggan melalui pelayanan yang unggul. Kualitas pelayanan yang unggul dan konsisten akan membuktikan pada pelanggan bahwa jasa yang digunakan adalah jasa yang terbaik, sehingga muncul nilai yang memberikan kepuasan yang membuat pelanggan akan menggunakan jasa pelayanan secara terusmenerus di kemudian hari. Kualitas 
pelayanan adalah tingkat keunggulan yang diharapkan dan pengendalian atas tingkat keunggulan tersebut untuk memenuhi keinginan konsumen (Tjiptono dan Chandra, 2014).

Menurut Lovelock, Wirtz and Mussry (2010:60) mengatakan "para pelanggan akan cukup terpuaskan selama penyelenggaraan yang dirasakan berada di antara zona toleransi, yaitu di atas tingkat layanan memadai”. PT. Astra Internasional Tbk. - Daihatsu Malalayang sebagai perusahaan yang menyediakan layanan penjualan dan purna jual kendaraan bermerek Daihatsu di Indonesia senantiasa mengedepankan layanan yang terbaik bagi pelanggan untuk memberikan pelayanan yang berkualitas sesuai dengan filosofi perusahaan "Daihatsu Sahabatku”. Dalam pra survey, peneliti menemukan adanya masalah di dalam subjek penelitian. PT. Astra International Tbk merupakan perusahaan yang bergerak di bidang penjualan mobil dan menerima permintaan service dari pelanggan. Hampir semua sistem yang ada sudah berbasis komputer. Namun, di dalam implementasinya pengerjaan masih kurang efisien. Jasa layanan service pada PT. Astra International Tbk yaitu kegiatan proses transaksinya seringkali berbelitbelit atau membutuhkan waktu yang cukup lama dikarenakan data yang akan di proses harus melewati beberapa tahap yang seharusnya dapat disingkat pada pengerjaannya. Dalam menghadapi persoalan ini, maka dibuatkan suatu sistem informasi layanan service pada PT. Astra International Tbk, guna untuk meminimalisir waktu, mengolah data transaksi menjadi informasi yang bermanfaat dengan cepat dan tepat. Sehingga adanya sistem ini diharapkan dapat memberikan konstribusi yang memadai untuk kelancaran kinerja perusahaan sehingga menghasilkan kepuasan pelanggan.

Dari uraian latar belakang diatas, maka penulis merasa tertarik untuk melakukan penelitian dengan judul: "Pengaruh Kualitas Pelayanan Terhadap Kepuasan Pelanggan Jasa Service Pada PT. Astra Internasional Tbk. $\quad-\quad$ Daihatsu Malalayang."

\section{Manajemen Pemasaran}

Menurut Alma (2013:130) manajemen pemasaran adalah proses untuk meningkatkan efisiensi dan efektivitas dari kegiatan pemasaran yang dilakukan oleh individu atau oleh perusahaan.

Sedangkan menurut American Marketing Association (Suhendi dan Sasangka, 2014:67) "manajemen pemasaran adalah perencanaan, pelaksanaan dan pengendalian operasi 
pemasaran total, termasuk tujuan perumusan tujuan pemasaran, kebijakan pemasaran, program pemasaran dan strategi pemasaran, yang ditujukan untuk menciptakan pertukaran yang dapat memenuhi tujuan individu maupun organisasi."

\section{Jasa}

Kotler dalam Lupiyoadi (2014:7) mengatakan bahwa "Jasa adalah setiap tindakan atau kegiatan yang dapat ditawarkan oleh satu pihak kepada pihak lain, pada dasarnya tidak berwujud dan tidak mengakibatkan perpindahan kepemilikan apapun. Produksi jasa mungkin berkaitan dengan produk fisik atau tidak."

Menurut Kotler dan Amstrong (2012:223), jasa memiliki 4 ciri utama yang sangat mempengaruhi rancangan program pemasaran, yaitu:
a. Tidak Berwujud (Intangibility)
b. Tidak
Dapat
Dipisahkan

\section{(Inseparability)}

c. Beraneka Ragam (Variability)

d. Tidak Tahan Lama (Perishability)

\section{Kualitas Pelayanan}

Zikmund, dkk dalam Suryadana dan Octavia (2015) mendefinisikan kepuasan adalah evaluasi setelah pembelian dari hasil perbandingan antara harapan sebelum pembelian dengan kinerja sesungguhnya.

Sampara dalam Hardiyansyah (2018:49) menyatakan bahwa kualitas pelayanan adalah pelayanan yang diberikan kepada pelanggan sesuai dengan standar pelayanan yang telah dibakukan sebagai pedoman dalam memberikan layanan. Adapun menurut Parasuraman dalam Lupiyoadi (2014:216) mengatakan bahwa kualitas pelayanan yaitu seberapa jauh perbedaan antara kenyataan dan harapan pelanggan atas pelayanan yang mereka terima.Menurut Tjiptono (2012) konsep kualitas pelayanan merupakan fokus penilaian yang merefleksikan persepsi konsumen terhadap lima dimensi pokok dan kinerja layanan, yaitu: Bukti Fisik (Tangible), Kehandalan (Reliability), Daya Tanggap (Responsiveness), Jaminan (Assurance), Empati (Empathy).

\section{Kepuasan Pelanggan}

Menurut Oliver dalam Tjiptono (2014:355) kepuasan pelanggan adalah evaluasi purnabeli antara persepsi terhadap kinerja alternatif produk atau jasa yang dipilih memenuhi atau melebihi harapan.

Ciri-ciri pelanggan yang puas menurut Kotler (2007:48) antara lain sebagai berikut: 
1) Loyal terhadap produk.

2) Adanya komunikasi dari mulut ke mulut yang bersifat positif.

3) Perusahaan menjadi pertimbangan utama.

\section{Metode Penelitian}

Pendekatan penelitian yang digunakan dalam penelitian ini adalah pendekatan penelitian kuantitatif. Penelitian dilakukan di PT. Astra International Tbk. - Daihatsu Malalayang yang beralamat di Jl. Wolter Monginsidi No. 123B, Malalayang Satu Barat. Adapun waktu penelitian kurang lebih satu bulan lamanya.

Populasi dalam penelitian yaitu seluruh pelanggan service dalam dua tahun terakhir yang berjumlah 8.400 pelanggan. Sampel dalam penelitian ini berjumlah 99 responden menggunakan penarikan sampel dengan rumus Slovin. Teknik pengambilan sampel yaitu convinience sampling, yaitu peneliti memilih sampel dari anggota populasi yang bersedia menjadi responden (Supramono 2005:66).

Metode pengumpulan data yaitu melalui kuesioner yang dibagikan kepada tiap pelanggan. Kuesioner diukur dengan model skala likert, yaitu digunakan untuk mengukur sikap, pendapat, dan persepsi seseorang.

\section{Analisis Regresi Linear Berganda}

Adapun persamaannya sebagai berikut:

$$
Y=b_{0}+b_{1} X_{1}+b_{2} X_{2}+b_{3} X_{3}+b_{4} X_{4}+
$$

$\mathbf{b}_{5} \mathbf{X}_{5}$

\section{Hasil Penelitian dan Pembahasan \\ Analisis Regresi Linear Berganda}

\begin{tabular}{lc|r|} 
& \multicolumn{2}{c}{ Unstandardized Coefficients } \\
Model & $\mathrm{B}$ & \multicolumn{1}{c|}{ Std. Error } \\
\hline (Constant) & .230 & 1.241 \\
\hline Bukti Fisik & .240 & .087 \\
\hline Kehandalan & .016 & .089 \\
\hline Daya Tanggap & .084 & .093 \\
\hline Jaminan & .099 & .092 \\
\hline Empati & .294 & .089 \\
\hline
\end{tabular}

Persamaan regresinya sebagai berikut:

$$
\begin{aligned}
& Y=0,230+0,240 X_{1}+0,016 X_{2}+0,084 X_{3} \\
& +0,099 X_{4}+0,294 X_{5}
\end{aligned}
$$

Berdasarkan persamaan tersebut, maka dapat dijelaskan sebagai berikut:

1) Koefisien konstanta sebesar 0,230 artinya jika tidak ada variabel bukti fisik, kehandalan, daya tanggap, jaminan, variabel empati, maka kepuasan pelanggan akan sebesar 0,230 poin.

2) Koefisien regresi variabel bukti fisik adalah 0,240 berarah positif, artinya setiap peningkatan pada kualitas bukti fisik sebesar 1 poin dan variabel lainnya tetap, maka kepuasan konsumen akan mengalami kenaikan sebesar 0,240 poin.

3) Koefisien regresi variabel kehandalan adalah 0,016 berarah positif, artinya setiap peningkatan pada kualitas kehandalan sebesar 1 poin dan variabel lainnya tetap, maka kepuasan 
pelanggan akan mengalami kenaikan sebesar 0,016 poin.

4) Koefisien regresi variabel daya tanggap adalah 0,084 berarah positif, artinya setiap peningkatan pada kualitas daya tanggap sebesar 1 poin dan variabel lainnya tetap, maka kepuasan pelanggan akan mengalami kenaikan sebesar 0,084 poin.

5) Koefisien regresi variabel jaminan adalah 0,099 berarah positif, artinya setiap peningkatan pada kualitas jaminan sebesar 1 poin maka kepuasan pelanggan akan mengalami kenaikan sebesar 0,099 poin.

6) Koefisien regresi variabel empati adalah sebesar 0,294 berarah positif, artinya setiap peningkatan pada kualitas kepedulian sebesar 1 poin maka kepuasan pelanggan akan mengalami kenaikan sebesar 0,294 poin.

\section{Uji t (Secara Parsial)}

a) Bukti Fisik (tangible) berpengaruh signifikan terhadap kepuasan pelanggan dengan nilai sig. sebesar $0,007<0,05$ dan nilai t hitung 2,767> $\mathrm{t}$ tabel 1,989. Sehingga dapat disimpulkan bahwa hasil pengujian $\mathrm{H}_{1}$ dalam penelitian ini diterima karena adanya pengaruh signifikan variabel bukti fisik terhadap kepuasan pelanggan. b) Kehandalan (reliability) tidak berpengaruh signifikan terhadap kepuasan pelanggan dengan nilai sig. sebesar 0,859>0,05 dan nilai t hitung $0,178<\mathrm{t}$ tabel 1,989 . Sehingga dapat disimpulkan bahwa hasil pengujian $\mathrm{H}_{2}$ dalam penelitian ini ditolak karena tidak adanya pengaruh signifikan variabel kehandalan terhadap kepuasan pelanggan.

c) Daya Tanggap (responsiveness) tidak berpengaruh signifikan terhadap kepuasan pelanggan dengan nilai sig. sebesar 0,372>0,05 dan nilai t hitung $0,898<\mathrm{t}$ tabel 1,989 . Sehingga dapat disimpulkan bahwa hasil pengujian $\mathrm{H}_{3}$ dalam penelitian ini ditolak karena tidak adanya pengaruh signifikan variabel daya tanggap terhadap kepuasan pelanggan.

d) Jaminan (assurance) tidak berpengaruh signifikan terhadap kepuasan pelanggan dengan nilai sig. sebesar 0,284 > 0,05 dan nilai t hitung $1,078<\mathrm{t}$ tabel 1,989. Sehingga dapat disimpulkan bahwa hasil pengujian $\mathrm{H}_{4}$ dalam penelitian ini ditolak karena tidak adanya pengaruh signifikan variabel jaminan terhadap kepuasan pelanggan.

e) Empati (empathy) berpengaruh signifikan terhadap kepuasan pelanggan dengan nilai sig. sebesar $0,001<0,05$ dan nilai t hitung 3,280> $\mathrm{t}$ tabel 1,989. Sehingga dapat 
disimpulkan bahwa hasil pengujian $\mathrm{H}_{5}$ dalam penelitian ini diterima karena adanya pengaruh signifikan variabel empati terhadap kepuasan pelanggan.

\section{Uji F (Secara Simultan)}

Variabel bukti fisik, kehandalan, daya tanggap, jaminan, dan empati secara bersama-sama berpengaruh terhadap Kepuasan Pelanggan. Hal ini karena nilai $\mathrm{F}$ hitung 21,858> F tabel 3,09 dan signifikansi $0,000<0,05$.

\section{Pembahasan}

\section{Pengaruh Variabel Bukti Fisik (Tangible) Terhadap Kepuasan \\ Pelanggan}

Variabel bukti fisik (tangible) adalah variabel yang berkenaan dengan daya tarik fasilitas fisik, perlengkapan, dan material yang digunakan perusahaan serta penampilan karyawan. Menurut Parasuraman, dkk (Lupiyoadi 2014) bukti fisik (tangible) yaitu kemampuan suatu perusahaan dalam menunjukkan eksistensinya kepada pihak eksternal. Berdasarkan hasil analisis koefisien regresi linear berganda menunjukkan arah hubungan yang positif (searah) antara bukti fisik dengan kepuasan pelanggan jasa service pada PT. Astra International Tbk. - Daihatsu Malalayang. Secara parsial variabel bukti fisik berpengaruh signifikan terhadap kepuasan pelanggan, dan hipotesis yang diajukan dapat diterima.

\section{Pengaruh Kehandalan (Reliability) Terhadap Kepuasan Pelanggan}

Merupakan kemampuan karyawan untuk memberikan jasa yang dijanjikan dengan handal dan akurat. Sebuah layanan yang handal adalah ketika seorang karyawan mampu memberikan pelayanan sesuai dengan yang dijanjikan dan membantu penyelesaian masalah yang dihadapi pelanggan dengan cepat. Berdasarkan hasil analisis koefisien regresi linear berganda menunjukkan arah hubungan yang positif (searah) antara kehandalan dengan kepuasan pelanggan jasa service pada PT. Astra International Tbk. - Daihatsu Malalayang. Secara parsial variabel kehandalan tidak berpengaruh terhadap kepuasan pelanggan, dan hipotesis yang diajukan ditolak.

\section{Pengaruh Daya Tanggap (Responsiveness) \\ Terhadap \\ Kepuasan}

Daya tanggap yaitu kemauan karyawan untuk membantu pelanggan dan memberikan pelayanan dengan cepat (responsive) dan tepat kepada pelanggan dengan penyampaian informasi yang jelas dan cepat menangani keluhan pelanggan. Berdasarkan hasil analisis koefisien regresi linear berganda menunjukkan arah hubungan yang positif (searah) antara daya 
tanggap dengan kepuasan pelanggan jasa service pada PT. Astra International Tbk. - Daihatsu Malalayang. Secara parsial variabel daya tanggap tidak berpengaruh signifikan terhadap kepuasan pelanggan, dan hipotesis yang diajukan ditolak.

\section{Pengaruh Jaminan (Assurance)}

\section{Terhadap Kepuasan Pelangggan}

Jaminan (assurance) yaitu pengetahuan, sopan santun, dan kemampuan karyawan untuk menimbulkan keyakinan dan kepercayaan. Menurut Parasuraman, dkk (Lupiyoadi 2014) jaminan yaitu pengetahuan, kesopansantunan, dan kemampuan para karyawan perusahaan untuk menumbuhkan rasa percaya para pelanggan kepada perusahaan. Berdasarkan hasil analisis regresi berganda menunjukkan arah hubungan yang positif (searah) antara jaminan dengan kepuasan pelanggan jasa service pada PT. Astra International Tbk. Daihatsu Malalayang. Secara parsial variabel jaminan tidak berpengaruh signifikan terhadap kepuasan pelanggan, dan hipotesis yang diajukan ditolak.

\section{Pengaruh Empati (Empathy)}

\section{Terhadap Kepuasan Pelanggan}

Merupakan kepedulian dan perhatian secara pribadi yang diberikan kepada pelanggan. Menurut Tjiptono dan Chandra (2014) empati (empathy) adalah kesediaan untuk peduli, memberikan perhatian dan pribadi kepada pelanggan. Berdasarkan hasil analisis koefisien regresi linear berganda menunjukkan arah hubungan yang positif (searah) antara empati dengan kepuasan pelanggan jasa service pada PT. Astra International Tbk. - Daihatsu Malalayang. Secara parsial variabel empati berpengaruh signifikan terhadap kepuasan pelanggan, dan hipotesis yang diajukan dapat diterima.

Dan merupakan variabel yang paling dominan berpengaruh terhadap kepuasan pelanggan.

6. Pengaruh Bukti Fisik, Kehandalan, Daya Tanggap, Jaminan dan Empati

\section{Terhadap Kepuasan Pelanggan}

Secara simultan kelima variabel tersebut memiliki pengaruh terhadap kepuasan pelanggan jasa service pada PT. Astra International Tbk. - Daihatsu Malalayang sebesar $54,0 \%$ dan sisanya $46,0 \%$ dipengaruhi oleh variabel lain seperti harga, persaingan, kompeten, komunikasi dan lain sebagainya yang tidak termasuk dalam penelitian ini. 


\section{Penutup}

\section{Kesimpulan}

Berdasarkan hasil penelitian dan pembahasan dapat ditarik kesimpulan sebagai berikut:

Secara parsial variabel bukti fisik dan empati yang berpengaruh signifikan terhadap kepuasan pelanggan jasa service pada PT. Astra International Tbk. Daihatsu Malalayang. Dan variabel yang paling dominan mempengaruhi kepuasan pelanggan jasa service pada PT. Astra International Tbk. - Daihatsu Malalayang adalah variabel empati (empathy) dengan nilai Beta variabel empati sebesar 0,340 lebih besar dari nilai variabel lain.

Secara simultan variabel bukti fisik (tangible), kehandalan (reliability), daya tanggap (responsiveness), jaminan (assurance), dan empati (empathy) bersama-sama berpengaruh terhadap kepuasan pelanggan dengan nilai koefisien determinasi sebesar $54,0 \%$ sisanya sebesar $46,0 \%$ dipengaruhi oleh faktor lain.

\section{Saran}

Hasil penelitian diketahui bahwa variabel empati yang paling dominan berpengaruh terhadap kepuasan pelanggan jasa service pada PT. Astra International Tbk. - Daihatsu Malalayang. Untuk itu, pihak manajemen diharapkan dapat mampu mempertahankan kualitas pelayanan karena mengingat semakin banyak dan semakin besar pula persaingan antar industri otomotif. Dan bagi penelitian selanjutnya, diharapkan untuk dapat meneliti variabel lainnya yang tidak termasuk dalam penelitian ini seperti harga, persaingan, kompeten, komunikasi dan lain sebagainya untuk menentukan seberapa besar kepuasan pelanggan disuatu perusahaan.

\section{Daftar Pustaka}

Hardiyansyah, 2018. Kualitas Pelayanan Publik. Bandung-Palembang: Gava Media.

Irjayanti, E., Tampi, J. R. E., dan Mukuan, D. D. S. 2018. Pengaruh kualitas Pelayanan Terhadap Loyalitas Pelanggan Pada Klinik Esther House of Beauty Manado (Studi Kasus Pada Pelanggan Klinik Esther House of Beauty Manado). Jurnal Administrasi Bisnis 6, http://garuda.ristekdikti.go.id.

Kotler, Philip dan Gary Armstrong. 2012. Dasar-Dasar Pemasaran, Edisi Kesembilan, Jilid 1, Penerbit PT. Indeks Kelompok Gramedia: Jakarta.

Lovelock C., Wirtz J., and Mussry J. 2010. Pemasaran Jasa - Perspektif Indonesia. Alih Bahasa: Wulandari D., dan Putera D. B. Jilid 1. Jakarta: Erlangga.

Lupioyadi. 2014. Manajemen Pemasaran Jasa: Teori Dan Praktek. Jakarta: Salemba Empat. 
Suhendi, Sasangka, I. 2014. Pengantar Bisnis. Bandung: Alfabeta.

Suryadana, M. L dan Vanny, O. 2015. Pengantar Pemasaran Pariwisata. Bandung: Alfabeta.

Tjiptono. 2012. Pemasaran Strategi. Yogyakarta: ANDI.

Tjiptono, Fandi dan Gregorius Chandra. 2014. Service Quality dan Satisfaction Edisi Ketiga. Yogyakarta: Andi Offset. 